\title{
ANALISIS COST-BENEFIT PELAKSANAAN CORPORATE SOCIAL. RESPONSIBILITY PROGRAM BOGASARI MITRA CARD SURABAYA
}

\author{
Wahyu Irawaty \\ Dianne Frisko \\ e-mail: dianne(a) ubaya.ac.id \\ Fakultas Ekonomi Universitas Surabaya
}

\begin{abstract}
One of the activities that company should do so maintain its sustainability nowadays is concern about society and environment by doing corporate social responsibility (CSR) activities. By doing CSR, company has shown their responsibility to all stakeholders aligned with the willingness to create sustainability development Company could use varied tools to asses their CSR activities in order to evaluate their CSR implementation. This research is aimed to analyze cost and benefit of one CSR programe of PT, ISM Tbk Bogasari Flour Mills, by using Socio-Economic Impact to evaluate its programme.
\end{abstract}

Keywords: Corporate Social Responsibility, Socio-Economic Impact

\section{PENDAHULUAN}

Eksistensi dan kinerja korporasi bisnis saat ini tidak hanya dilihat dari seberapa profit atau laba yang dihasilkan tiap periodenya, bal ini berkenaan dengan pemenuhan kewajibannya untuk memenuhi harapan shareholdernya. Namun saat ini juga dipertimbangkan bagaimana peranan dan tanggungjawab yang diberikan penusahaan ke-pada para stakeholder-nya yang meliputi customer, pemerintah, masyarakat umum, dan lainlain, seperti yang di ungkapkan oleh Korten bahwa dunia bisnis selama setengah abad terakhir, telah menjelma menjadi institusi yang paling berkuasa di planet ini. Dapat disadari bahwa tindakan nyata yang diambil korporasi membawa dampak terhadap kehidupan manusia, terhadap individu, masyarakat, dan seluruh kehidupan di bumi. Peranan korporasi bisnis dalam memberikan tanggung jawab sosial dikarenakan setiap aktivitas yang dilakukan oleh perusahaan mulai dari saat pengiriman bohan baku sampai menjadi barang jadi, aktivitas operasional perusahaan dapat memberikan bunyak sekali dampak, diantaranya perusakan lingkungan, kebisingan dan polusi saat proses produksi, ataupun kurangnya jaminan keselamatan dari para pekerjanya. Salah satu wujud pertanggungjawaban korporasi bisnis modern kepada para stakeholder (pihak yang berkepentingan) dinyatakan melalui kegiatan Corporate Social Responsibility (CSR) yang merupakan tanggung jawab etis dan sosial yang semestinya dilakukan dengan sukarela atas kemausn sendiri, bukan karena keterpaksaan pihak manapun.

Melihat iklim industri di luar negeri, penerapan CSR oleh kalangan dunia bisnis telah banyak dilakukan, sedangkan di Indonesia, untuk mendukung pengimplementasian CSR, pada Juli 2007 Pemerintah memberlakukan Undang-undang Perseroan Terbatas (UU P'T) pasal 74 yang menekankan kewajiban untuk melaksanakan tanggung jawab sosial pada penusahaan yang bidang usahanya bersangkutan dengan mengelola sumber daya 
alam. Sebagian perusahaan di Indonesia menilai kegiatan CSR dari sisi pengeluaran biaya yang dihubungkan dengan pembangunan masyarakat (community derelopment), maupun upaya menghindari kerusakan lingkungan. Perusahatan menilai manfaat yang diperoieh dari CSR cenderung bersifat intangible, sehingga bagi perusahaan analisis biaya-manfaat kegiatan CSR sulit dilakukan.

Menunt survey yang dilakukan Quatter of al (2003) menyimpulkan pentingnya perusahaan menganahisis biaya-manfaat kegiatan sosialnya dalam konsep akuntansi sosial. Manfaat duri akuntansi sosial bugi perusahaan tidak terbatas pada meningkatnya kinerja perusahaam, transparansi dan akuntabilitas, namun menjadi alat evaluasi dan pembelajaran bagi organisasi, dan perbaikan yang sistematís media komunikasi dengan stakeholer. Melalui metode ini, sejumlah perusahaan yang menjalankan CSR mencatat hasil yang signifikan. Huskey Injection Molding Lid, menginvestasikan dana USS 4,2 juta untuk aktifitas CSR, manfaat yang diterima perusahaan mampu mengurangi biaya USS 13,2 juta, atau menghemat USS 9 juts.

Penelitian int menganalisis biayn dan manfatt dengan pendekatan nocio economic impoct terhadap salab satu program CSR PT. ISM Tbk Bogasari Flour Mills yang berimplikasi pada bidang sosial, ekonomi, dan lingkungan. Dan penelitian ini, fokus pada program Bogasari Mitru Card (BMC) yang berlokusi di Surabaya. Adapun tujuan dan manfaat analisis ini, diharapkan dapat memberi informasi pitak perusahaan șcbagai dasar evaluasi kinerja internal manajemen dalam program BMC untuk digunakan dalam proses pengambilan keputusan manajerial.

\section{TELAAH TEORETIS}

\section{Pengukuran Pelaksanaan CSR dengan Pendekatan Akuntansi Sosial}

Menurut Elkington bahwa semua bisnis perlu mengukur kesuksesannya tidak hanya berdasarkan pada pengukuran kinerja secara tradisional (seringkali dinyatakan dalam profit, Return on Investment, atau pendapatan yang didapat oleh shareholder) tetapi juga dampak yang luas yang mereka berikan terhadap ekonomi, lingkungan dan masya. rakat yang berada diwilayah usahanya (Savitz and Weber 2003). Hal ini dirumuskan sebagai tanggung jawab sosial bisnis melalui konsep triple bottom line utau "Tiga P" yakni People, Planet. Profit. Dimana fokus utama bisnis bukan hanya laba, tetapi juga manusia dan juga planet (Wibisono 2007). Kaplan dan Norton (1996) juga menyatakan bahwa di-perlukan suatu alat untuk mengukur dan menjzclola kinerja dengan cara menyeim-bangkan ukuran keuangan dan ukuran non-keuangan, dalam sasaman jangka pendek dan sasaran jangka panjang, serta digunakan sebagai alat untuk menerjemahkan visi, misi, dan strategi bisnis badan usaha, yang dikenal dengan Balanced Scorecard.

Dari dua pemikiran diatas lahirlah Corporate Social Responsibility (CSR), dimana menurut Trimidad dan Tobaco Bureau of Standards menyatakan bathwa Coprorate Social Responsibility diartikan sebagai komitmen usaha untuk bertindak secara etis, beroperasi secarı legal, dan berkontribusi untuk peningkatan ekonomi bersamaan dengan peningkatan kualitas hidup dari karyawan dan keluarganya, komuniti lokal dan masyarakat secara lebih luas (Budimanta dan Prasetijo 2004). World Business Council for Sustainable Development menyatakan bahwa Corporate Social Responsibility atau tanggung jawab perusahaan secari sosial sdalah komitmen bisnis untuk berkontribusi dalam pembangun- 
an ekonomi betkelanjutan, bekerja dengan para karyawan perusahaan, keluarga karyawan tersebut, berikut para komuniti setempat (lokal) dan masyarakat secara keseluruhan, dalam rangka meningkatkan kualitas kehidupan (Budimanta dan Prasetijo 2004). Dari kedua definisi ini dapat disimpulkan bahwa Corporate Social Responsibility merupakan tanggung jawab sektor bisnis dalam kaitannya dengan semua pihak yang terlibat, memengaruhi, dan terkena dampak dari sebuah kegiatan bisnis.

Meskipun tujuan utamanya adalah menghasilkan keuntungan, sebuah perusahaan tidak terlepas dari masyarakat. Pertama, pendiri dan pemilik sebuuh perusahean adalah individu bagian dari masyarakat, eksekutif pengelola senta karyawannya adalah individuindividu anggota masyanakat. Kedua, tujunn menghasilkan keuntungan tidak mungkin tercapai tanpa adanya masyarakat, yang menjadi pasar bagi produknya. Karena sebuah kegiatan bisnis tidak dapat dilepaskan dari masyarakat, kegiatan bisnis sudah pasti membawa dampak bagi masyarakat dan elemen-elemen yang adu didalamnya serta lingkungan tempat hidup masyarakat tersebut.

Menurut Tanaya (2004) pada umumnya perusahaan enggan untuk melaksanakan CSR karena meli-hat bal tersebut hanyt sebagai pusat pengeluaran (cost centre), CSR memang tidak mem-berikan manfast keuangan dalam jangka pendek, namun CSR akan memberikan hasil baik langsung maupun tidak langsung pada keuangan perusahaan di masa mendatang. Oleh karena itu, berbugai program CSR lebih tepat bila digolongkan ke dalam pusat investasi (investment centre).

Dan untuk mengukur kinerja dan kebcrhasilan CSR, meaurut Wermasubun (2003) dapat digunakan pendekatan social accounting, dimana social accounting adalah suatu metode untuk melihat sejauh mana perusahaan memenuhi tujuan-tujuan sosial dan etis yang telah direncanakannya. Dalam evaluasi keberhasilan suatu program sosial adalah penting supaya dana yang sudah digunakan dalam program tersebut tidaklah sia-sia, tetapi memberikan hasil sesuai dengan pengorbanan ekonomis maupun non ekonomis yang sudah diberikan. Keberhasilan suatu program dapat dilihat melalui dampak program tersebut bagi banyak pihak. Pengukuran terhadap dampak program dapat dilakukan dengan pendekatan dampak sosial ekonomi (socio-economic impact). Kelebihan dari pengukuran berdasarkan dampak sosial ekonomi adalah pihak manajemen dapat mengetahui langkah selanjutnya yang harus diambil untuk menjaga kelangsungan dan meningkatkan hasil pengukuran yang akan terlihat dari pengaruh program yang dilakukan kepada publik terutama publik yang menjadi target layanan.

\section{Pendekatan SocioEconomic Impact Dalam Menganalisis Biaya dan Manfat}

Menurut Quarter et al (2003) terdapat beberapa metode yang daput digunakan untuk mengukur akuntansi sosial yang dapat digunakan oleh akuntansi manajemen, sehingga dampak sosial dari kegiatan organisasi dapat terlihat. Salah satu metode tersebut adalah SocioEconomic Impacz. Dimana pendekatan ini menghasilkan SocioEconomic Impact Statement guna melaporkan kegiatan operasional organisasi. Model ini dapat digunakan oleh berbagai jenis organisasi karena informasi yang disediakan adalah mengenai dampak dari imput yang ada dalam menghasilkan output. SocioEconomic Impact Siatement tidak terfokus pada net income (nenemue-appense) tetapi pada arus sumber daya sosial dan moneter yang berasal dari stakeholder dan mengalir kembali kepada stakeholder. Pada kolom infows menunjukkan aris masuk yang diberikan organisasi kepada stakeholder. Sedangkan kolom oufflows menunjukkan arus keluar yang diberikan 
oleh stakeholder organisasi. Pada kolom net impact menunjukkan selisih dari anus sumber daya yang diberikan kepada stakeholder dari arus sumber days yang berasal dan stakeholder.

\section{METODE DAN DATA PENELTTIAN}

Penelitian ini dilakukan pada PT. ISM Tbk Bogasari Flour Mills, dengan meneliti lebih detil terhadap salah safu program CSR-nya ynitu program Bogasari Mitra Card untuk lokasi Surabaya. Penelitian ini menggunakus pendekatan kualitatif dengan metode perolehan data dilakuican melalui wawancara yang bersifat seni-structured secara mendalam kepada narusumbet internal perusahnan dulam bal ini manajemen Bogasari, maupun luar penusahaan mcliputi masyarakat yang terlibat langsung dalum pelaksanaan kegiatan CSR Bogasari diantaranya bebcrapa orang dari UKM. Selain itu juga dilakukan pengamatan langsung yang bersifat mon-participant observation dengan mengamati aktifitas UKM anggota Bogasari Mitra Card di lapangan. Metode analisis dokumen yang diperoleh dari dokumentasi Bogasari terkait dengain program CSR, turut melengkapi kebutuhan perolehan data penelitian ini, dimana kesemun metode perolehan data dan informasi terbatas dalam periode waktu 2006-2007, yang dilnkukan oleh penulis pada tiap narasumber secara langsung di lapangan (field study).

\section{HASIL PENELITIAN DAN PEMBAHASAN}

Bogasari merupakan salah satu divisi dari PT. Indofood Sukses. Makmur yang memiliki visi, misi serta 5 falsafah yang merupakan landasan, pedoman dan tujuan dari seluruh aktivitas yang dilaksanakan oleh PT.ISM Tbk Bogasari Flour Mills, dan sebagai wujud dari pengimplementasian salah satu falsafah yaitu kepedulian, Bogasari melaksanakan tanggung jawab sosialnya. Peran CSR bagi PT. ISM Bogasari Flour Mills tidak hanya sebagai alat untuk meningkatkan reputasi perusahaan semata, namun sudah menjadi komitmea dari tanggung jawab sosial yang harus diberikan pada stakefoler-nya yang meliputi pemegang saham, pemerintah, konsumen, pekerja, maupun masyarakat.

Dalam melakukan tanggung jawab sosialnya Bogasuri berusaha memberikan yang terbaik bagi para pemangku kepentingan, yang diterjemahkan dalam konsep Bogasari Excellence dimana dari sinilah pemikiran tentang program-program CSR dirancang sesuai visi dan misi perusahaan, dan menghasilkan Panca Bhakti PT. ISM Bogasari Flour Mills, dengan 3 tujuan utama, yaitu meningkatkan Shareholder Vahe dalam hal ekonomi dan sosial; menciptakan daya saing lebih besar dan kesuksesan dalam jangka panjang: serta meningkatkan reputasi perusahaan. Program-program CSR dirancang dan dikembangkan sesuai dengan 5 fokus utama (Panca Bhakti) meliputi : building luman capital; protecting the enviromment; encouraging good governance; assessing sacial cohesion; serta strengthening economies.

Didalam Panca Bhakti yang ke 5 yaitu program Bogasari Mitra Card (BMC) dirancang dan dimplementasikan, dengan tujuan meningkatkan perekonomian. Ide awal dari program BMC yaitu selain untuk memberikan pertanggungiwaban sosial kepada para stakeholder, juga untuk memberikan reward kepada pelanggan langsung dari produk Bogasari yang berupa tepung terigu, yaitu kepada Usaha Kecil Menengith (UKM) bukan pada agen ataupun retailer. 
$\mathrm{Hal}$ ini disebabkan jumlah pelanggan langsung Bogasari memiliki presentase paling besar, hal ini dibuktikan dari niset yang diadakan Bogasari yaitu sekitar $70 \%$ pengguna Bogasari $60 \%$ diantaranya adalah pengguna langsung yang sebagian besar merupakan UKM, sedangkan 10\% merupakan industri besar.

Tujuan pihak manajemen Bogasari dalam membuat long-term planning ingin menjembatani UKM dan Lembaga Keuangan (Bank) guna membantu pengembangan usahanya, yang diwujudkan dalam salah satu program yaitu Bogasari Mitra Card (BMC). Dari tujuan ini maka pihak manjemen Bogasari membuat rangkaian fasilitas yang diberikan untuk mencapai tujuan yang ada. Program BMC ini memiliki 2 daerah pusat tanggung jawab, yaitu Bogasari Jakarta dengan wilayah tanggung jawab Indonesia bagian barat sebanyak \pm 17.500 anggota, sedangkan Bogasari Surabaya bertanggung jawab atas Indonesia bagian timur dengan jumlah anggota $\$ 7.500$.

\section{Analisis Biaya Program BMC dari Sudut Pandang Manajemen Bogasari}

Untuk menjalankan program BMC ini, Bogasari bekerja sama dengan beberapa bank swasta, dimana untuk setiap anggota BMC akan diberikan beberapa fasilitas yaita: hadiah langsung dan hadiah undian; e-wallet; bogasari baking centre; asuransi; dan majalah wacana mitra. Pemberian fasilitas ini dari sudut pandang manajemen Bogasari dianggap sebagai biaya. Adapun perhitungan masing-masing fasilitas menurut sudut pandang Bogasari: hadiah langsung, hadiah undian, E-wallet, Bogasari Baking Center, Majalah Wacana Mitra, asuransi.

\section{Hadiah Langsung}

Hadiah Langsung ini di berikan tiap 3 bulan sekali, dan dalam setahun terdapat 4 kali pemberian hadiah langsung oleh Bogasari untuk tiap anggota BMC. Hadiah ini diberikan sesuai dengan poin yang diperoleh tiap anggota. Poin ini didapat jika anggota BMC membeli tepung terigu sebanyak I sak yang berisi $25 \mathrm{~kg}$, di agen khusus BMC dengan mengisi slip penjualan (pada sistem lama) ataupun mengisi langsung e-kupon yang terdapat pada karung/sak $25 \mathrm{~kg}$ (pada sistem baru). Dimana perhitungannya $5 \mathbf{s a k}=1$ poin. Dan berikut ini contoh cara perhitungan poin Bogasari:

I poin x......(@) harga terendah tepung terigu produk Bogasari per $\mathrm{kg}$ )

Misal: harga tepung terigu merek semar $=\underline{80.000}=3200 / \mathrm{kg}$

10 poin $\times 3200^{* \hbar *}=$ Rp. 32.000

$$
25 \mathrm{~kg}
$$

\section{** Hadiah Undian Hadiah Langsung*}

* Nominal uang ini akan ditransfer melalui account Bank masing-masing para anggota BMC, dimana hal ini merupakan Hadiah Langsung ( 3 bulanan).

**. Jumlah poin ini akan dikut sertakan pada Hadiah Undiun ( 6 bulanan).

*** Merupakan angka pengali yang digunakan.

Ada berbagai perhitungan Biaya Bogasari untuk Hadiah Langsung. Perhitungan biaya untuk hadiah langsung meliputi biaya untuk anggota pemegang BMC tipe Silver; biaya untuk anggota pemegang BMC tipe Gold, dan biaya untuk anggota pemegang BMC tipe Platinum. 
Perhitungan Biaya untuk Anggota Pemegang B MC Tipe Silver Biaya untuk anggota pemegang $\mathrm{BMC}$ tipe Silver yaitu: Rata-rata penggunaan tepung terigu oleh anggota BMC Silver sebanyak 15 sak dalam 1 minggu dengan masa aktif produksi 6 hari, dengan kata lain sekitar $2,5 \mathrm{~kg}$ tepung terigu yang digunakan selama seminggu, dan jenis tepung yang digunakan Segitiga Biru, dan angka pengati yang digunakan sebesar Rp. 2500, angku pengali ini berasal dari hargit tepung termurah Bogasari (sumber: data internal Bogasari)

Dengan begitu, berarti poin yang didapat jika dihitung tiap bulan sebanyak 12 poin dengan asumsi I bulan terdapat 4 minggu dan total poin hadialh langseng tiap 3 bulanan sebesar 36, sehingga jumlah uang yang dikeluarkan Bogasari untuk 1 anggota BMC Silver sebesar Rp. 90.000 , diketahui jumlah unggota BMC Silver 5.250 peserta, sehingga total uang yang dikeluarkan Bogasari Rp. 472.500.000 dalam I kali hadiah langsung, jika dalam safu tahun terdapat 4 kali pemberian hadiah langsung maka total biaya pada Bogasari uatuk BMC tipe Silver Rp, 1,890,000,000 dalam setahun (Juni 2006-Juli 2007).

Perhitungan Biaya untuk Anggota Pemegang BMC Tipe Gold Biaya untuk Anggota Pemegang BMC Tipe Gold Biaya untuk anggota pemegang BMC tipe Gold yaitu:Rata-rata penggunaan tepung terigu oleh anggota BMC Gold sebanyak 15 sak sehari dengan masa aktif produksi 6 hari seminggu, dan ratn-rata menggunakan jenis tepung Kereta Kencana dan Kunci Biru, dan angka pengali yang digunakan Rp. 2500,00.

Berarti poin yang didapat jika dihitung tiap bulan sebanyak 90 poin dengan asumsi dalam 1 bulan terdapat 30 hari dan total poin untuk hadiah langung tiap 3 bulanan sebesar 270 , dengan angka pengali Rp. 2.500 sehingga jumlah uang yang dikeluarkan Bogasari untuk 1 anggota BMC Gold sebesar Rp, 675.000, dan jumlah anggota BMC Gold yaitu 1.500 sehingga total uang yang dikeluarkan Bogasari Rp. 1.012.500.000 dalam 1 kuli hadiah langsung, jika dalam satu tahun terdapat 4 kali pemberian hadiah langsung maka total biaya pada Bogasari untuk BMC fipe Gold Rp. 4.050.000.000 dalam setahun (periode Juni 2006- Juli 2007).

Perhitungan Biaya untuk Anggota Pemegang BMC Tipe Platinum Biaya umtuk anggota pemegang BMC tipe Platinum yaitu:Sedangkan rata-rata penggunaan tepung terigu oleh anggota BMC Platinum sebanyak 50 sak sehari dengan masa aktif produksi 6 hari seminggu, dan rata-rata menggunaksn jenis tepung Kereta Kencana dan Kunci Biru, dan angka pengnli yung digunakan sebesar Rp. 2500.

Berarti poin yang didapat jika dihitung tiap bulan sebanyak 300 poin dengan asumsi dalam 1 bulan terdapat 30 hari dan total poin untuk hadiah langung tiap 3 bulanan sebesar 900 , dengan angka pengali Rp. 2.500 sehingga jumlah uang yang dikeluarkan Bogasari untuk 1 anggota BMC Platinum sebesar Rp. 2.250.000, dan jumlah anggota BMC Platinum yaitu 750 sehingga total uang yang dikeluarkan Bogasari $R p$. 1.687.500.000 dalam I kali hadiah langsung, jika dalam satu tahun terdapat 4 kali pemberian hadiah langsung maka total biaya pada Bogasari untuk BMC tipe Platinum Rp. 6.750.000.000 dalam setahun (periode Juni 2006- Juli 2007). Dari perhitungan diatus, diketahui total biaya dikeluarkan untuk hadiah langsung sebesar $\mathrm{Rp}$. 12.690.000.000. 


\section{Hadiah Undian}

Dalam satu tahun hadiah undian ini diundi dua kali, dan semua biays yang dikeluarkan merupakan tanggung jawab bersama antara Bogasari Jakarta dan Surabaya, dan karena jumlah anggota Bogasari Surabaya lebih sedikit dibanding dengan anggota Bogasari Jakarta maka pembebanan biaya untuk hadiah undian ini tidak sama rata, dengan kata lain Bogasari Jakarta menanggung lebih besar dibanding Bogasari Surabaya. Hadiah yang diberikan dalam undian antara lain: Hadiah Grand Prize: 2 Mobil Daihatsu Terios ; berikutnya 5 paket Umroh/ tour yang sejenis; 30 Sepeda Motor Suzuki Spin; 45 Lemari Es Sanyo; 45 Televisi flat 21" Sanyo; 150 Mini Compo Polytron; serta 700 Cook Ware Kirin. Dari total hadiah diatas, Surabaya mengcover: 1 Mobil Daihatsu Terios, 2 Paket Unroh' tour yang sejenis, 10 Sepeda Motor Suzuki Spin, 20 Lemari Es Sanyo, 20 Televisi Flat 21" Sanyo, 50 Mini Compo Polytron, 250 Cook Ware Kirin.

Dan untuk mengetahui total biaya yang dikefuarkan, digunakan harga pasar sebagai estimasi harga perolehan. Estimasi total biaya yang dikeluarkan untuk Hadiah Undian adalah sebagai berikut:

1 Mobil Daihatsu Terios, dengan estimasi harga Rp. 147.000.000

2 Paket Umroh/ tour yang sejenis, dengan estimasi harga Rp. 15,000,000, untuk 1 paket Umroh sehingga total untuk 2 paket Umroh sebesar Rp. 30.000 .000

10 Sepeda Motor Suzuki Spin, dengan estimasi biaya Rp. 12.000.000 per unit motor. sehingga total biaya untuk 10 unit sepeda motor Rp. $120,000.000$

20 Lemari Es Sanyo, estimasi biaya (a) Rp. $1.400,000$, schingga total biaya untuk 20 unit lemari es sebesar Rp. $28.000,000$.

20 Televisi Flat 21" Sanyo, estimasi biaya Rp. 1.680.000 untuk tiap unit televisi 21", total biaya untuk 20 televisi sebesar Rp. 33.600 .000

50 Mini Compo Polytron, estimasi biaya Rp. 780.000 untuk tiap unit mini compo, total biaya untuk 50 mini compo sebesar Rp. 39.000 .000 .

250 Cook Ware Kirin, estimasi biaya Rp. 250.000 untuk tiap unit cook ware, total biaya untuk 250 unit cook ware sebesar Rp. 62.500 .000

Total biaya untuk 1 kali Hadiah Undian sebesar Rp. 460.000.000. Karena Hadiah Undian dilakukan 2 kali dalam setahun maka total biaya yang dikeluarkan sebesar $\mathrm{Rp}$. 920.000 .000 , total biaya ini ditambah dengan sewa gedung dan biaya lain-lain dengan estimasi sebesar Rp, 200.000 .000 , karena Bogasari Surabaya menjadi tuan rumah untuk pengundian Hadiah Undian periode Desember 2006 yang diadakan di PTC Mall di Surabaya, sehingga total keseluruhan biaya yang dikeluarkan untuk Hadiah Undian sebesar Rp, 1.120.200.000,-

\section{E-wallet}

E-Wallet merupakan kerjasama antara BMC Surabaya dengan Bank Permata. Ewallet adalah kartu ATM yang dimiliki oleh setiap anggota BMC, dimana kartu ini digunakan untuk memudahkan pihak Bogasari dalam memberikan Hadiah Langsung kepada pelanggannya, seperti tujuan dari Bogasari bahwa ingin menjebatani para UKM anggotanya agar dapat bekerjasama dengan lembaga keuangan untuk mengembangkan usahanya. Karena fasilitas yang diberikan Bogasari kepada anggota BMC ini berasal dari kerjasama antara Bogasari dan Bank Permata, maka diasumsikan tidak ada biaya yang keluarkan 
karena antara Bogasari dan Bank. Permata saling diuntungkan, keuntungan ini lebih pada meningkatnya branding dari masing-masing.

\section{Bogasari Baking Center (BBC)}

Dalam 1 bulan pelatihan yang diadakan oleh BBC sekitar 14 pelatihan, dan harga rata-rata sebesar Rp. 175,000, jika dalam sebulan sekitar 94 anggota BMC yang ikut BBC maka biaya Bogasari atas diskon 10\% yang diberikan, sebesar Rp. 23,030.000 sebulan, maka dakam setahun total biaya yang dikeluarkan sebesar Rp. 276.360.000,-

\section{Majalah Wacana Mitra}

Syarat mendapatkan Majalah Wacana Mitra yaitu jika dalam 6 bulan terdapat pembelian minimal 1 poin ( 5 sak berisi $25 \mathrm{~kg}$ tepung terigu). Estimasi biaya pokok produksi dari majalah Wacant Mitra sebesar Rp, 4,500. Dengan jumlah anggota yang memenuhi syarat sebesar 1,125 anggota, maka biaya yang dikeltarkan untuk majalah Wacana Mitra untuk I bulan sebesar Rp, 10.125.000, sehingga diketahui total biaya dalam setahun sebesar Rp. 121.500.000,-

\section{Asuransi}

Dengan memberikan fasilitas asuransi ini maka Bogasari mengeluarkan biaya sebesar Rp. 5,600.000 per tahun untuk asuransi kecelakaan dan Rp. 7.500 .000 pertahun untuk asuransi kesehatan. Sehingga estimasi biaya yang dikeluarkan Bogasari untuk fasilitas asuransi ini sebesar Rp. 3.152.800,000 untuk asuransi kesehatan yang diterima oleh pemegang BMC Silver, Gold, dan Platinum. Sedangkan untuk asuransi kesehatan prevensia sebesar Rp. 420.000 .000 yang hanya diterima oleh pernegang BMC Platinum. Sehingga total biaya untuk asuransi sebesar Rp. 3572.800.000. Dari perhitungan diatas, diketahui total biaya yang dikeluarkan Bogasari untuk salah satu wujud aktifitas CSR atas fasilitas yang diberikan untuk anggota BMC dalam 1 tahun (Juni 2006 - Juli 2007) sebesar Rp. 17.780.860.000,-

\section{Analisis Manfaat Program BMC bagi Manjemen Bogasari dan Stakeholder.}

Dalam menjalankan program BMC ini sebagai salah satu perwujudan dari tanggungjawab sosial perusahaan, Bogasari tidak hanya mengeluarkan biaya besar yang sia-sia, namun disini akan dihitung berapa manfaat yang didapatkan oleh Bogasari dengan keberadaan program BMC ini baik yang kunlitatif maupun yang dapat dikuantitatifkan. Seperti yang telah dibahas tentang amalisis biaya yang dikeluarkan dari program BMC ini, maka imbalan berupa benefit yang dapat diambil dari analisis manfaut diuraikan dari tiap komponen analisis biaya program BMC, yang diuraikan secara detil dibawah ini.

\section{Hadiah Langsung}

Hadiah langsung memberi dampak banyak UKM lainnya yang belum tergabung anggota $\mathrm{BMC}$ ingin ikut serta menjadi anggota $\mathrm{BMC}$. Terlihat dari total jumlah anggota BMC tahun 2004, saat pertama kali diadakan program BMC terdapat sekitar 17,500 anggota, sedangkan tahun 2007 terdapat 25.000 anggota, sehingga terdapat kenaikan seki- 
tar $10 \%$ tiap tahunnya. Dan $75 \%$ UKM yang menjadi obyek interview mengatakan mereka senang dengan badiah langsung, dikarenakan dapat digunakan membantu secara langsung usaha mereka karena sifatnya moneter. Dengan demikian secara tidak langsung dengan adanya implementasi program BMC ini, jumlah pelanggan Bogasari meningkat, dan hal ini menyebabkan kenaikan jumlah penjunlan pada periode-periode berikutnya. Asumsi tahun 2007 ada 25.000 anggota BMC makit tahun 2008 menjadi 27.500 anggota, ada tambahan anggota sebanyak 2.500 UKM, jika UKM ini mengkonsumsi sehari 5 sak tepung terigu dengan jenis Segitiga Biru dengan harga Rp. 86.750 per sak $(25 \mathrm{~kg})$ dengan masa produksi 6 hari dalam seminggu dan satu bulan 30 hari, maka Bogasari akan mendapa tambahan pendapatan sebesar Rp. $312.300,000.000$ *-

\section{Hadiah Undian}

Dengan adanya Hadiab Undian, para UKM maupun masyarakat disekitar dacrah diadakannya pengundian hadiah tersebut dapat berperan serta. Karena setiap pengundian Bogasari akan mengundang beberapa perwakilan UKM berasal dari tiap tipe kartu yang dipegang, sehingga menimbulkan rasa kekeluargaan antara Bogasari dan UKM, ataupun antar sesama UKM, selain itu diadakan acara lomba memasak yang berbasis tepung terigu yang diikuti oleh seluruh lapisan masyarakat yang berminat, serta adanya tips memasak atau membuat makanan yang berbasis tepung terigu, dengan demikian Bognari ikut membantu menambah pengetahuan memasak ataupun cara mengolah makanan berbasis tupung kepada pira pengunjung, serta Bogasari mempererat tali persaudaraan antar UKM, dan juga membuat kebanggaan tersendiri bagi UKM yang berkesempatan untuk mengundi secara langsung Hadiah Undian sehingga mereka menjadi lebih loyal kepada Bogasari, dan pengalaman ini bisa diceritakan kepada UKM lain, dan membuat UKM lainnya menjadi aktif lagi.

Selain itu, bagi UKM yang mendapat hadiah undian akan mendapatkan untung, selain hadiah tersebut bisa membantu operasional kegiatan usahi mereka, mereka juga tambah loyal dan mendapatkan kebanggaan karena nama dan usaha mereka akan masuk didalam majalah Wacana Mitra yang dikonsumsi oleh seluruh anggota BMC diseluruh Indonesia. Semua keuntungan yang dihasilkan atau diberikan dari adanya badiah undian ini bersifit kualitatif, karena bersifat pengetahuan, perasaan bangga dan senang, schingga sulit dikuantifikasi tolok ukurnya.

\section{E-wallet}

Keberadaan E-wallet, memberi fasilitas yang aman bagi para podagang yang tergabung dalam BMC untuk menabung, dan memudahkan mereka untuk menyimpan uang. Selain itu Bogasari juga berperan serta dalam menambah pengetahuan para anggota BMC, karena sebagian dari mereka belum pernah menabung ataupun berhubungan dengin pihak bank sebelumnya, dengan adanya program ini mereka jadi lebih sadar akan manfaat menabung dibank. Sedangkan Bank Permata selaku partner dalam program ini juga mendipatkan banyak keuntungan yaitu kenaikan jumluh customer dan branding di. antara para UKM anggota BMC. Semua keuntungan ini tidak bisa di kuantifikasi karena bersifat pengetahuan dan branding. 


\section{Bogasari Baking Centre}

Dengan adanya Bogasari Baking Center, Bogasari dapat meningkatkan hubungan dan loyalitas para UKM, karens melalui program pelatihan ini, ditumbah dengan pemberian potongan harga keikutsertaan, maka Bogasari ikut serta dalam mencerdaskan dan menambah pengetahuan khususnya tentang pengolahan bahan makanan berbasis tepung terigu yang bernilai jual. Pengetahuan ini diakui sangat berguna bagi usaha yang dijalankan para UKM, dan memberikan motivasi bagi orang-orang yang ingin mendirikan usaha baru.

\section{Majalah Wacana Mitra}

Majalah Wacana Mitra menjadi penghubung utau jembatan informasi antara Bogasari dan anggotanya. Bogasari dapat berkomunikasi lebih dekat dengan mereka karena dalam majalah tersebut memuat banyak sekali topik dan bahasan, selain itu banyak sekali ilmu mengelola usaha maupun resep-resep tentang aneka makunan berbasis tepung. sehingga hal ini dapat membantu menambah pengetahuan para UKM.

\section{Asuransi}

Dengan adanya Asuransi ini, Bogasari mendapat tambahan kepercayaan dan loyalitas dari para anggotanya, karena dapat membantu meringankan beban mereka. Selain itu Bogasari dapat menambah partner kerjasuma dengan pihak asuransi, dengan penawaran premi istimewa bagi anggota BMC, disis lain pihak Bogasari juga membantu pihak asuransi mendapatkan customer dan penambahan pendapatan dari progrum BMC ini, sehingga ini juga merupakan perwujudan CSR.

\section{Analisis kuantifikasi Inflows dan Outflows Resource}

Tujuan program BMC ini digunakan sebagai key performance indicator atas pengimplementasian program CSR, yang digunakan sebagai penilaian kinerja dan keberhasilan program BMC. Indikator Kinerja tersebut meliputi: mempertahankan cus: tomer; meningkatkan loyalitas castomer kepada Bogasari, serta meningkatkan hubungan antara customer dengan Bogasari.

Performance Indicator akan digunakan dalam mengukur kesuksesan program BMC ini dan untuk mengetahui apakah program BMC ini memberikan manfaat kepada stakeholder sesuai dengan harspan dan tujuan program BMC sebagai salah satu perwujudan CSR dari Bogasari. Oleh sebab itu, peneliti melakukan wawancara dengan 15 UKM sebagai perwakilan dari anggota BMC Surabaya, untuk lebih mengetahui secara langsung tentang mantaat dan tingkat keberhasilan Bogasari untuk mencapai tujuannya.

Beberapa metode pengukuran dengan indikator kinerja untuk menilai manfaat yang diperoleh anggota BMC, yang dilakukan penulis menunjukkan beberapa hasil yang diuraikan sebagai berikut. Pengukuran dengan menjuring pendapat 15 UKM di Surabaya dengan indikator harapan mereka menjadi anggota BMC , telah menunjukkan hasil $93 \%$ menyatakan harapan mereka menjadi anggota BMC untuk mendapat hadiah dan fasilitas lain; mendapatkan barga produk tepung yang lebih murah; serta ingin mendapatkan tambahan pengetahuan pengelolaan usaha melalui keanggotaan BMC. 
Pengukuran kedua dilakukan dengan wawancara langsung kepada 15 UKM mengenai keuntungan atas fasilitas yang didapatkan anggota BMC, dan basilnya 13 UKM menyatakan mereka mendapatkan hadiab langsung, 2 UKM menyatakan tidak tahu menerima hadiah atau tidak karena malas mengecek saldo bank; 5 UKM menyutakan menerima Hadiah Undian; 10 UKM menyatakan memanfastkan E-wallet; dan 3 UKM menyatakan jarang memanfaatkan E-wallet; 2 UKM menyatakun malas memanfaatkan E. wallet; 3 UKM menyatakan pernah mengikuti $\mathrm{BBC} ; 13$ UKM menyatakan tiap bulan mendapat Majalah Wacana Mitra; 4 UKM menyatakan mengetahui adanya fasilitas asuransi, namun belum pernah menggunakan; 10 UKM menyatakan tidak tahu tentang adanya fasilitas asuransi ini; dan 1 UKM menyatakan mau mengikuti fasilitas ini.

Pengukuran berikutnya berupa pengumatan langsung terhadap proses produksi mereka dengan menggunakan tepung terigu Bogasari, dan hasilnya 15 UKM menggunakan tepung Bogasari, dimana rata-rata mengunakin tepung terigu jenis Segitiga Biru, Gunung Bromo, Cakra, Kefefa Kencana, Rata-rata UKM dengan jenis usaha mic, akan menghasilkan mie yang kenyal (tidak mudah patah) dan berwarna kuning cetah, serta tahan lama (tidak mudah basi). Selanjumya, UKM dengan usuha roti atau bakery menghasilkan roti yang empuk dan tahan luma (tidak mudah berjamur), sebagai anggota BMC mereka mengetahui cara mengolah bahan makanan secara higienis dan bersih.

Selanjutnya, peneli mengukur tingkat kepuasan 15 LKM yang menjadi anggota BMC. Hasil dari pengukuran tersebut, peneliti menemukan 12 UKM merasa puas dengan menjadi anggota BMC; 2 UKM merasa belum terlalu puas karena ada beberapa harapan mereka yang belum tercapai: I UKM menyatakan tidak merasakan sama sekali keuntungan menjadi anggota $\mathrm{BMC}$.

Indikator diatas kita dapat mengetahui manfast yang dirasakan oleh para UKM selama menjadi anggota BMC. Adapun tujuan pengukuran ini untuk dapat dijadikan media evaluasi pihak BMC karena belum 100\% dari UKM yang menjadi obyek penelitian menyatakan puas dan mendapatkan manfaat menjadi anggota BMC. Schingga diharapkan dengan adanya evaluasi secara periodik dapat membantu pihak Bogasari melakukan perbaikan dan mencapai tujuan pengimplementasian program BMC.

Dari biaya dan manfaat serta performance indicator yang sudah diperoleh, selanjutnya akan dibuat analisis kuantifikasi inflows (manfaat yang diterima masyarakat) dan outflows resources (biaya yang dikeluarkan masyaraknt) untuk program BMC yang dapat digunakan untuk informasi dan evaluasi pihak internal Bogasari.

\section{Bugan 1}

Kuantifikasi Inflows Resources dan Ouffowes Resources pada Program BMC

\begin{tabular}{|c|c|c|}
\hline & Joflues Resmences & Outhour Resioarces \\
\hline 0 & 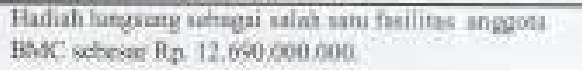 & \multirow{5}{*}{ 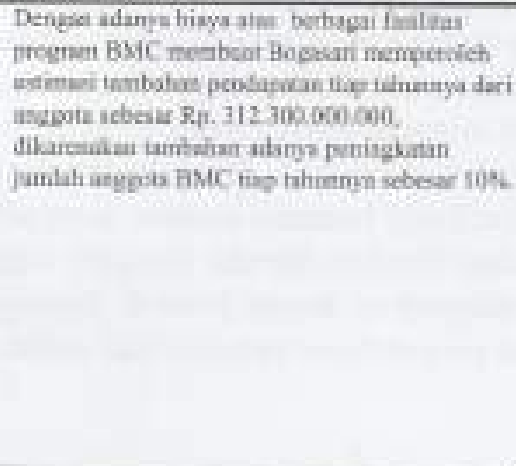 } \\
\hline 0 & 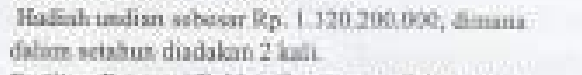 & \\
\hline 0 & 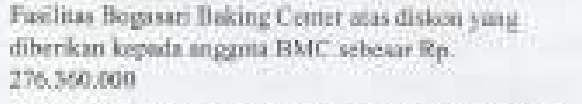 & \\
\hline 0 & 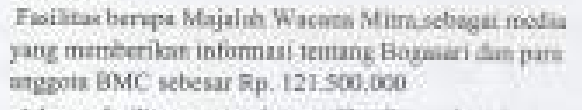 & \\
\hline 0 & 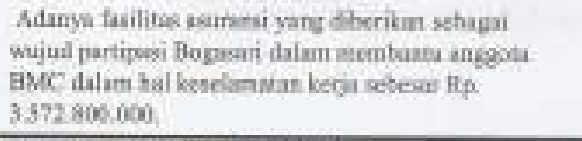 & \\
\hline
\end{tabular}


Bagan 1 menampakkan inflows resources dan ouflows resources pada program BMC, Pada bagan tersebut tampak bahwa kontribusi diberikan Bogasari kepada salah satu stakeholennya yaitu UKM melalui program BMC sebesar Rp. 17.780.860.000, dan juga dapat dilihat pada oufflows resources yang didapat oleh Bogasari yaitu penambahan pendapatan atas adanya program BMC sebesar Rp. $312.300,000,000$. Hal ini membuktikan bahwa pengimplementasian CSR Bogasari melalui program BMC yang terencana dengan baik telah memberikan dampak yang cukup baik kepada masyarakat dalam hal ini UKM dan juga memberi manfaat bagi Bogasari.

Dari pengukuran berdasarkan inflows dan outflows resources dapat diketahui tentang biaya dan manfaat secata finansial, seiring dengan itu masih ada kontribusi lain dari pelaksanaan program BMC Bogasari yang bersifat nonfinansial yang tidak dapat dikuantifikasikan ke dalam ukuran moneter. Manfaut yang borsifat nonfinansial tetapi tidak bisa dikuantitatifkan tampak pada bagan 1 berikut dengan urainn detil dibawahnya.

Tabel 1

Informasi Non Financial dengan pendekatan socio-economic impact

\begin{tabular}{|l|l|l|}
\hline Indikator Kinerja & Hasil Pesgukuras & Secial Impact \\
\hline & & \\
\hline
\end{tabular}

Indikator non financial pertama yaitu menjaga hubungan baik dengan anggota BMC, dengan hasil pengukuran menunjukkan bertambahnya jumlah customer yg menggunakan fasilitas BMC tiap tahunnya, sehingga dapat ditarik kesimpulan bahwa para UKM yang menjadi anggota mendapatkan manfaat dari fasilitas yang ditawarkan program BMC, sehingga mereka tetap menggunakan produk Bogasari sebagai bahan baku usahanya. Sementara itu sisi dampak sosial meliputi Bogasari dapat mengupdate data UKM pelanggannya, hingga menjalin hubungan lebih dekat dengan UKM; pada saut UKM anggota BMC menerima manfantnya, mereka ikut serta dalam membangun perekonomian daerah Surabaya, dengan mengajak UKM lainnya untuk mengikuti program BMC ini; Bogasari memiliki hubungan kerjasama yang semakin baik dengan bank karena jumlah anggota BMC tiap tahun selalu bertambah, dampak sosial berikutnya adalah bertambahnya pengetahuan bagi para UKM tentang perbankan dan fasilitasnya.

Indikator kinerja berikutnya adalah meningkatkan loyalitas anggota BMC, yang menunjukkan hasil bahwa bertambahnya kuantitas pembelian tepung terigu Bogasari yang dilakukan anggota BMC, karena mereka mengetahui banyak keuntungannya,hingga mereka setia terhadap Bogasari, Informasi dampak sostal yang terkait adalah $70 \%$ usaha berbasis tepung menggunakan produk Bogasari; UKM anggota BMC semakin pandai dalam mengelola usahanya; semakin banyak ide untuk membuat inovasi produk yang dihasilkan, sebagai dampak mengikuti BBC dan membaca Majalah Wacana Mitra; serta dampak mengikuti pelatihan tentang pengolahan produk membuat produk yang dihasilkan UKM berkualitas baik dan higienis. Selain itu Bertambahnya keyakinan anggota BMC untuk tetap memakai produk Bogasari sebagai pilihan pertama untuk usaha berbasis tepung terigu, mengakibatkan loyalitas tehadap Bogasari naik. 
Indikator kinerja terkait kualitas hubungan anggota BMC dengan bogasari memberikan hasil pengukuran bahwa banyaknya jumlah media atau fasilitas yang digunakan untuk meningkatkan hubungan antara para UKM dan Bogasari yaitu melalui Majalah Wacana Mitra, Buku mengenai pengusaha berbasis tepung terigu, fonum-forum diskusi,dan lain-lain. Ditinjau dari dampak sosialnya memperlihatkan Bogasari dapat menjaga hubungan baik dengan para UKM juga Bank Permata sebagai partner dalam program BMC ini; Para UKM merasa lebih diperhatikan olch Bogasari, sehingga tercipta sussana keterbukaan untuk bercerita dan berbagi masalah, berbagi tips, dan informasi terkait usaha mereka, terciptanya rasa aman yang dirasakan para UKM karena adanya fasilitas asunansi dari keanggotaan BMC. Dari informasi nonfinansial ini diharapkan Bogasari dapat mengetałui lebih dalam mengenai kinerja tanggung jawab 5osialnya melalui pelaksanaan program BMC,

Selanjutnya untuk kepentingan internal manajemen mengukur seberapa besar biaya yang dikeluarkan dan manfast yang diperoleh dari program ini, penulis membuat Laporan biaya dan manfaat dengan pendekatan SocioEconomic Impact berdasar konsep akuntansi sosial seperti tampak pada tabel 3. Net inflows sebesar (Rp. 294 519.140,000) menunjukkan bahwa sumberdaya yang mengalir ke Bogasari (outfow resources) lebih besar dibandingkan dengan sumberdaya yang dikeluarkan Bogasari sebagai cost pelaksanaan program BMC, hal ini berarti dampak atau manfaat yang diterimn oleh perusahaan sangat besar atas pengimplementasian program BMC sebagai salah satu aktifitas CSR Bogasari. Tetapi hal ini tidak berarti pihak Bogasari ingin mencari untung semata, melainkan merupakan hasil dari pengimplementasian CSR secara baik dan memiliki tujuan yang spesifik sehingga capaian yang dibarapkan telah sesuai dan dapat dipertanggung jawab. kan pada pilhak manajemen intemal Bogasari dan stakeholer.

Manfaat yang diperoleh Bogasari dapat dirasaknn langsung karena sesuai dengan Panca Bhakti Bogasari. Dimana, program BMC merupakan program CSR yang berimplikasi langsung pada perekonomian, sehingga dampaknya pada perekonomian lebih mudah untuk diketahui. Namun evaluasi harus dilakukan secara periodik dan penyusunan turget tujuan harus lebih spesifik, agar pihak manajemen dapat dengan mudah lagi dalam mengevaluasi kinerja program BMC tiap periode.

Tahel 3

SocioEconomic Impact Statement

Program Bogasari Mitra Card wilayah Surabaya

Periode Juni 2006-Juli 2007

\section{Inflows Resources}

\begin{tabular}{lrr}
\hline Biaya Hadiah Langsung & Rp. & $12,690,000,000$ \\
Biaya Hadiah Undian & Rp. & $1,120,200,000$ \\
Biaya BBC & Rp. & $276,360,000$ \\
Biaya Majalah Wacana Mitra Rp. & $121,500,000$ \\
Biaya Asuransi & Rp. & $3,572,800,000$
\end{tabular}

Rp $17,780,860,000$

Outflows Resources

Penambahan Pendapatan

Rp. $312,300,0000,000$

Total ousflows resources

$\operatorname{Rp} 312,300,000,000$

Somber Inkernut Bugessat delah 
Berdasar informasi yang didapatkan, penulis melihat adanya analisis biaya dan manfaat yang dilakukan oleh PT. 1SM Tok, Bogasari Flour Mills selama ini belum sempurna mengingat sangat terbatasnya laporan yang dibuat pihak internal manajemen. Keterbatasan tersebut disebabkan oleh anggapan perusahaan bahwa program BMC merupakan salah satu program dari pengimplementasian CSR yang bersifat sukarcla dan sebagai cost cenire, sehingga mengenai biaya dan manfaatnya tidak perlu dihitung secara rinci.

Walaupun masih belum sempurna, perhitungan biaya dan manfaat sangat diperlukan mengingat dalam melakukan kegiatan sosial sekalipun, perusahan menggunakan sumberdaya internal perusahaan. Selain itu, analisis biaya dan manfaat dapat digunakan untuk mengetahui secara pasti mengenai dampak yang diberikan kepada stakeholdernya, sehingga dapat dijadikan sumber informasi untuk evaluasi efektifitas dan keberhasilan program pelaksanaan CSR perusahaan.

\section{KESIMPULAN}

Dengan menggunakan pendekatan akuntansí . 50sial dapat diketahui dampak sosial ekonomi terhadap masyarakat luas terutama para anggota usaha kecil menengah (UKM) dari pelaksanaan program Bogasari Mitra Card ini, sehingga kegunaan dan manfaat program dapat diketahui. Selain itu juga dapat diketahui sejauh mana program tersebut telah bethasil, dan yang belum tercapai, serta hal-hal apa saja yang perlu ditingkatkan lagi. Hal ini masih belum sepenuhnya dilakukan oleh internal manajemen Bogasari, atas programprogram aktifitas CSR-nya karena pengukuran hanya dilakukan saat program akan dijalankan, tidak secara periodik:

PT. ISM Tbk, Bogasari Flour Mills memiliki banyak program sebagai wujud pengimplementasian CSR. Dari pengimplementasian program-program tersebut banyak sekali melibatkan stakeholder, sehingga diharapkan PT, ISM Tbk, Bogasari Flour Mills dapat lebih meningkatkan lagi pertanggung jawaban yang diberikan kepada stakeholdernya. Disisi lain untuk kepentingan internal manajemen, hal ini untuk mengungkapkan bahwa pengimplementasian CSR bukan hanya merupakan cost center semata, namun dapat berupa investment center jika disusun dan direncanakan dengan baik dan konsisten.

PT. ISM Tbk, Bogasari Flour Mills dapat menggunakan socioeconomic impact dalam melakukan analisis biaya dan manfaatnya. Dengan bantuan analisis biaya dan manfaat dengan pendekatan laporan socioeconomic impact, Bogasari dapat mengevaluasi kekurangan dan menetapkan target kedepan secara lebih terarah, dimana tercapainya tujuan aktifitas CSR adalah jika manfaat yang diberikan kepada masyarakat lebih besar atau minimal sama dengan yang diterima perusabaan diukur dari saldo net inflow yang positif pada analisis pelaporan tersebut. Hal ini mempermudah perusahaan untuk melihat dampak sosial yang diberikan secara jelas, sehingga dapat digunakan untuk mengevaluasi apakah program CSR telah sesuai dengan panca bhakti sebagai landasan nilai-nilai Bogasari. Manfaat lain informasi yang tersaji dalam analisis socioeconomic impact dapat dijadikan pertimbangan pengambilan keputusan internal pihak manajemen PT. ISM Tbk, Bogasari Flour Mills dalam mengimplementasikan program-program CSR lainnya. 


\section{DAFTAR PUSTAKA}

Budimanta Arif, Prasetijo Adi, Rudito Bambang 2004, Corporate Social Responsibility, Indonesia Center for Sustainable Development, Jakarta

Kaplan, Robert S, Norton David P. 1996, Balanced Scorecard: Translating Strategy Into Action, Harvard Business School Press, New York

Laporan Program Corporate Social Responsibility Bogasari 2006, Reaching The Future - CSR Practices in Bogasari, Jakarta

Quarter Jack, Mook Lauric, Richmond Betty J. 2003, What Counts. Social Accounting for Nonprofit and Cooperative, Prentice Hall, USA

Savitz W., Andrew, Wcber Karl 2006, The Triple Bottom Line, $l^{\text {si }}$ ed, San Francisco, USA

Tanaya Jimmy 2004, Tanggung Jawab Sasial Korporasi, The Business Watch Indonesia dan Novib Oxfam Netherlands, Surakarta

Wermasubun Savio D. 2003, 'Corporate Social Responsibility,' The Business Watch Indonesia, Surakarta

Wibisono Yusuf 2007, Membedah Konsep dan Aplikasi Corponate Social Responsibility, Fasco Publishing, Gresik. 